\title{
ANALYZING PODCAST APPLICATION TO IMPROVE LISTENING ABILITY
}

\author{
Widi Rafidah Agarid ${ }^{1}$, Maulida Nurzahra ${ }^{2}$ \\ IKIP Siliwangi \\ 1'widirafidahagarid23@gmail.com, ${ }^{2}$ mnurzahra@gmail.com
}

\begin{abstract}
The aim of this research is to find out whether Podcast Applications (learning english-free english podcast listening application) that was released by the British Council, will help to improve listening ability. While listening to the episode, on screen will appear script that what student listen. It is make listeners to know what discussed in it. The purpose of the use of this application is that the student can improve listening ability with continuous listening and getting used to being in an English environment.This research is qualitative research with case study method. The research finding showed that podcast application could improve student ability. After heard the podcast, the students could understand, received and respond the speakers of the application. It is indicates that the application is very useful for learning English especially in listening ability with an easier way and in accordance in this era.
\end{abstract}

Keywords: Podcast Listening, Podcast application, Application to improve listening

\section{INTRODUCTION}

Smartphones and the Internet is a unity that cannot be separated. Everyone needs both to be able to work, get information, news, entertainment, even studying while using the internet. Students of this era is not always having to come to the campus to study when teaching learning process can be done with online.

No exception to the students of English Program at IKIP Siliwangi as well. They utilize their smartphone and Internet to study too. However, they have some limitations in English ability. Especially in listening ability. This is caused due to the lack of English, Their environment that is less supportive, less adequate facilities and other things. "Listening is the process of receiving, constructing meaning from, and responding to spoken and/ or nonverbal messages" (An ILA Definition of Listening, 1995). One of the solutions to reach communicative with other people is listening. Listening is one of skills that students needs. However, listening ability such as the big problem in english skills. Nicholes (1981) describes some familiar characteristics of poor listening: (1) condemning a speaker's subject as uninteresting; (2) criticizing the speaker's delivery rather than focusing on the message; (3) preparing an answer to a point or question before comprehending it; (4) listening only for facts; (5) wasting the advantage of thought speed over speech speed; (6) tolerating or creating distractions; (7) faking attention; (8) permitting personal prejudices to interfere; (9) avoiding difficult material; and (10) attempting to take outline notes even when the message isn't structured to be outlined. Acording to Gutierrez (2009: 21) the listener's purpose in listening varies from situations to situations; each purpose has its own requirements and skill that are needed to achieve the goals of communication process (1) to obtain and exchange basic information, thus; gaining knowledge, (2) to make intellectual judments and fair criticisms as well as evaluate ideas, (3) to seek enjoyment, entertainment, and pleasure; (4) to give logical and intelectual answers. Listening is a complex process an integral part of the total 
communication process. Kline (1996: 15) explained process of listening are: (1) Receiving, this step is easily understood. For example someone give information to the others. (2) Attending, it is attention can be given to only one stimulus at a time. And necessary attention to only a limited number of stimulus at the same time. (3) Understanding, a message may have been sent and received and the receiver may have attended to the message. (4) Responding, the listening process since effective communication and effective listening may be define as accurate sharing or understanding of meaning. But a responds may be needed or at least helpful. (5) Remembering, memorization of facts in listening process wtih short term memory, information is used immediately within a few second for example as with a phone number. Long term memory allows use to recall information and events hours, days, weeks even year laters we remembered.

One of the famous internet platform is Google. Google has been providing millions of source verified credentials or applications with educational organizations such as the British Council's. British Council has launched several applications of learning English through movies, podcasts, games and quizzes. The application can be downloaded via Google playstore, Apple store and windows Phone store. Based on these issues, researchers did the research on the use of applications from British Council to improve listening ability using English Podcast Application. This application focuses on the capability listening of the users. There are several features on this application, the most important is the audio and scrip regarding some general topic which can be downloaded for free and played offline, then there are tips on learning English

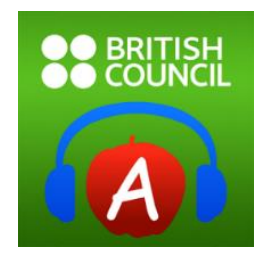

Figure 1. British Podcast Application

Where "Learning english podcast" appeared. User can download episodes and watch it for online or offline, while reading the written script. User may choose at random, some existing series, and free to download many episodes users want. As an example. The researchers chose $1^{\text {st }}$ series and 1 st episodes to download.
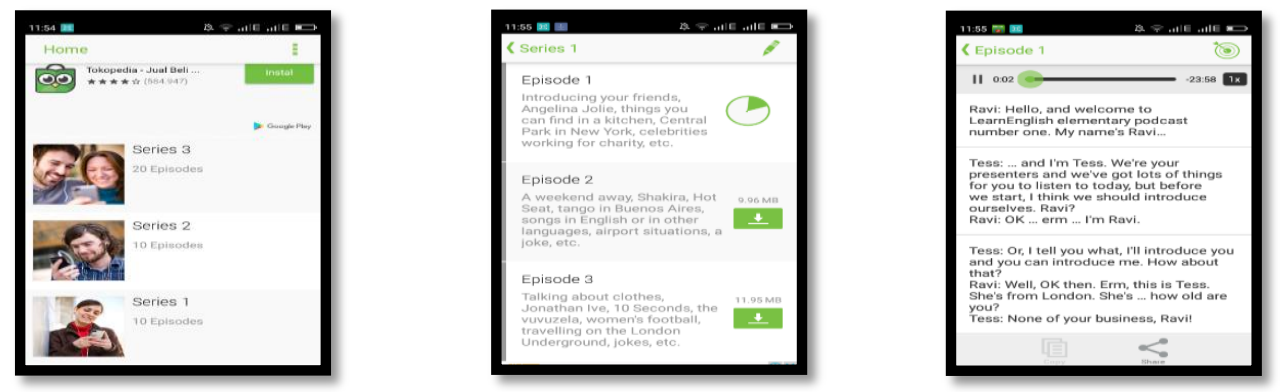

Figure 2. Podcast menu and podcast script 


\section{METHOD}

In this research the researchers would use qualitative research design and use case study method. There were students of IKIP Siliwangi as population and the sample were 5 students at non-regular class. The data collection was conduct 5 question, as follow:

1. What do you know about "Learning English Podcast - Free English Listening Application"?

2. What are the function of this "Learning English Podcast - Free English Listening Application"?

3. What are "Learning English Podcast - Free English Listening Application" in?

4. How were your English in listening ability improving after listen this application?

5. What are the benefit and the weakness of this application?

Then the researcher analyzed data using the interview research. Data of this research were analyzed by experience of the sample.

\section{RESULTS AND DISCUSSION}

\section{Result}

In this result the researchers describes and discussed the data of this research in the use of "Learning English Podcast - Free English Listening Application" based on interview. The results from 5 students as bellow:

Table 1. Result of the interview

\begin{tabular}{|c|c|c|c|c|c|c|}
\hline \multirow{2}{*}{ No } & \multirow{2}{*}{ Questions } & \multicolumn{5}{|c|}{ Answers } \\
\hline & & Student 1 & Student 2 & Student 3 & Student 4 & Student 5 \\
\hline 1 & $\begin{array}{l}\text { What do you } \\
\text { know about } \\
\text { "Learning } \\
\text { English } \\
\text { Podcast - } \\
\text { Free English } \\
\text { Listening } \\
\text { Application"? }\end{array}$ & $\begin{array}{l}\text { Podcast } \\
\text { application is } \\
\text { the medium } \\
\text { for learning } \\
\text { english } \\
\text { which, could } \\
\text { be } \\
\text { downloaded } \\
\text { on } \\
\text { smartphone } \\
\text { as free. }\end{array}$ & $\begin{array}{l}\text { Yes, it is } \\
\text { learning } \\
\text { english } \\
\text { application } \\
\text { from british } \\
\text { counsil. }\end{array}$ & $\begin{array}{l}\text { It is one of } \\
\text { learning } \\
\text { English way } \\
\text { as a base on } \\
\text { application }\end{array}$ & $\begin{array}{l}\text { it is an } \\
\text { application } \\
\text { for english } \\
\text { learning to } \\
\text { improve } \\
\text { listening } \\
\text { ability. }\end{array}$ & $\begin{array}{l}\text { Yes, this is } \\
\text { an } \\
\text { application } \\
\text { to improve } \\
\text { listening } \\
\text { skills. }\end{array}$ \\
\hline 2 & $\begin{array}{l}\text { What are the } \\
\text { function of } \\
\text { this } \\
\text { "Learning } \\
\text { English } \\
\text { Podcast - } \\
\text { Free English } \\
\text { Listening } \\
\text { Application"? }\end{array}$ & $\begin{array}{l}\text { To make } \\
\text { learning } \\
\text { english } \\
\text { easier and } \\
\text { improve four } \\
\text { skills in } \\
\text { English } \\
\text { especially } \\
\text { listening } \\
\text { ability. }\end{array}$ & $\begin{array}{l}\text { of course it } \\
\text { is to improve } \\
\text { listening } \\
\text { ability. }\end{array}$ & $\begin{array}{l}\text { Yes, it is } \\
\text { helping me } \\
\text { to learn } \\
\text { english. }\end{array}$ & $\begin{array}{l}\text { It is a } \\
\text { medium for } \\
\text { learning } \\
\text { English, a } \\
\text { tool for } \\
\text { practice } \\
\text { listening } \\
\text { ability. }\end{array}$ & $\begin{array}{l}\text { to improve } \\
\text { listening } \\
\text { ability }\end{array}$ \\
\hline
\end{tabular}




\begin{tabular}{|c|c|c|c|c|c|c|}
\hline 3 & $\begin{array}{l}\text { What are } \\
\text { "Learning } \\
\text { English } \\
\text { Podcast - } \\
\text { Free English } \\
\text { Listening } \\
\text { Application" } \\
\text { in? }\end{array}$ & $\begin{array}{l}\text { There are } \\
\text { home menu, } \\
\text { include some } \\
\text { episode } \\
\text { series, and } \\
\text { script. }\end{array}$ & $\begin{array}{l}\text { It has home } \\
\text { menu, some } \\
\text { series, } \\
\text { episodes and } \\
\text { script that } \\
\text { equal with } \\
\text { the episodes }\end{array}$ & $\begin{array}{l}\text { There are } \\
\text { menu, eps, } \\
\text { series and } \\
\text { yes inside } \\
\text { the episode } \\
\text { the speaker } \\
\text { talking about } \\
\text { art, celebrity, } \\
\text { story, } \\
\text { history, and } \\
\text { many more. }\end{array}$ & $\begin{array}{l}\text { Conversation } \\
\text { soundtrack, } \\
\text { exercises, } \\
\text { and script. }\end{array}$ & $\begin{array}{l}\text { Home, list of } \\
\text { episode } \\
\text { series start } \\
\text { from beginer } \\
\text { stage to } \\
\text { profesional } \\
\text { stage, and } \\
\text { has } 20 \\
\text { episodes. } \\
\text { But, it's not } \\
\text { always has } \\
\text { complete } \\
\text { episode, it's } \\
\text { depend on } \\
\text { theme of } \\
\text { series and } \\
\text { script that } \\
\text { appropriate } \\
\text { with the } \\
\text { track }\end{array}$ \\
\hline
\end{tabular}

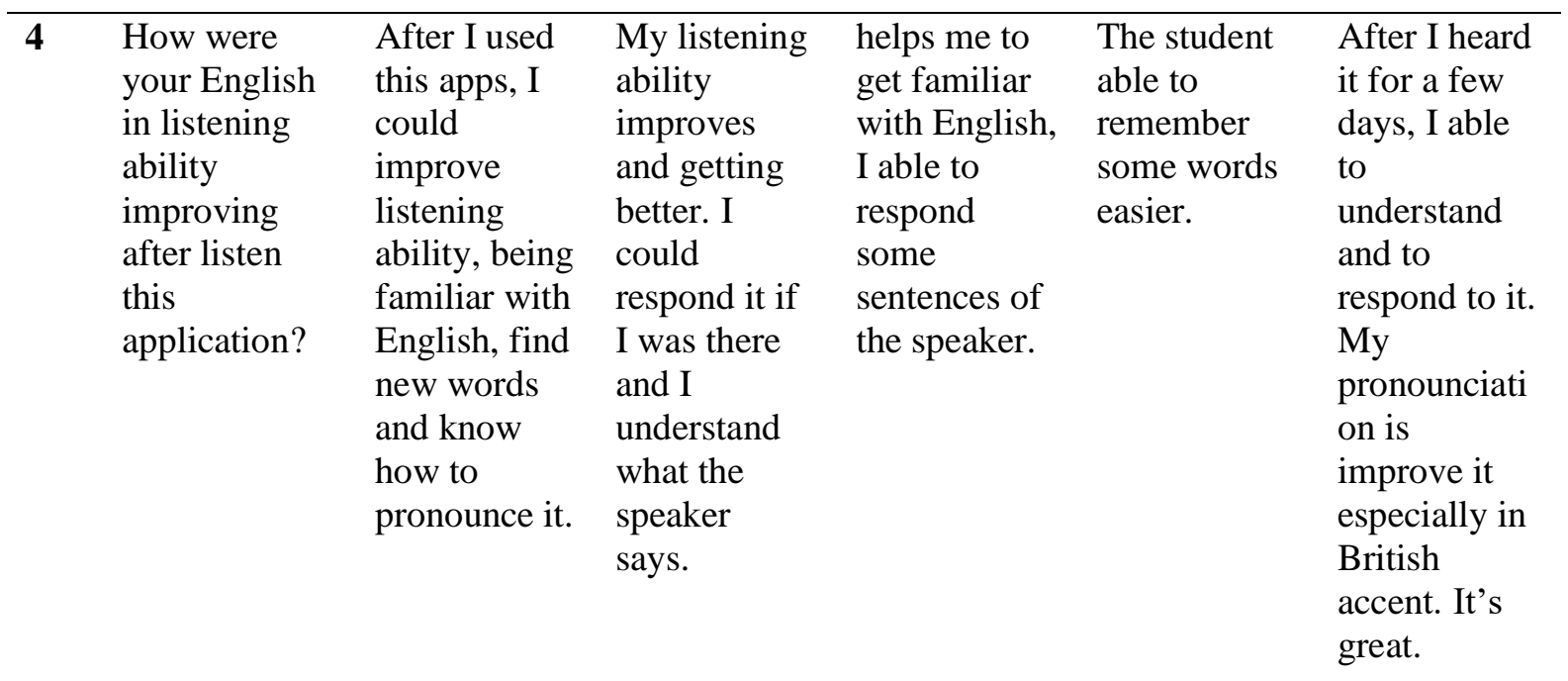




\begin{tabular}{|c|c|c|c|c|c|}
\hline $\begin{array}{ll}5 & \text { What are the } \\
\text { benefit and } \\
\text { the weakness } \\
\text { of this } \\
\text { application? }\end{array}$ & $\begin{array}{l}\text { Benefit: this } \\
\text { apps coulsd } \\
\text { depelove my } \\
\text { listening and } \\
\text { pronounciati } \\
\text { on abilities. } \\
\text { Smartphones } \\
\text { is a medium } \\
\text { that is } \\
\text { always used } \\
\text { by people, so } \\
\text { that podcast } \\
\text { app could } \\
\text { open } \\
\text { anytime and } \\
\text { anywhere, } \\
\text { it's free for } \\
\text { download. } \\
\text { Weakness: } \\
\text { there are } \\
\text { some } \\
\text { websites that } \\
\text { require paid } \\
\text { subscription. } \\
\text { Using gadget } \\
\text { excessively } \\
\text { makes } \\
\text { people } \\
\text { become an } \\
\text { individual } \\
\text { person. } \\
\text { Might couse } \\
\text { everdepende } \\
\text { nce on } \\
\text { technology } \\
\text { over time. }\end{array}$ & $\begin{array}{l}\text { Benefit: this } \\
\text { app has } \\
\text { simple } \\
\text { menu, the } \\
\text { speaker is } \\
\text { attractive, } \\
\text { therefore I } \\
\text { feels like } \\
\text { being part of } \\
\text { it. It's free to } \\
\text { download } \\
\text { too. } \\
\text { Weakness: } \\
\text { none, its } \\
\text { great app }\end{array}$ & $\begin{array}{l}\text { Benefit: it } \\
\text { has many } \\
\text { benefit for } \\
\text { me, I mean } \\
\text { this app is } \\
\text { helping me } \\
\text { to learn } \\
\text { English more } \\
\text { esier and } \\
\text { fun. } \\
\text { Weakness: } \\
\text { it's online }\end{array}$ & $\begin{array}{l}\text { Benefit: this } \\
\text { app can be } \\
\text { gotten easily } \\
\text { and free, but } \\
\text { there is no } \\
\text { quiz } \\
\text { available in } \\
\text { this app. } \\
\text { Weakness: } \\
\text { we have to } \\
\text { send email } \\
\text { before to get } \\
\text { quiz. }\end{array}$ & $\begin{array}{l}\text { Benefit: it's } \\
\text { good for my } \\
\text { smartphone } \\
\text { RAM, I can } \\
\text { download } \\
\text { new episode } \\
\text { and delete } \\
\text { the last } \\
\text { episode. } \\
\text { Weakness: } \\
\text { no, it's nice. }\end{array}$ \\
\hline
\end{tabular}

\section{Discussion}

Based on the result of interview above, the researchers concluded that all the participant of this research know about podcast application and how to operated it, then they also aware about the purposes of this application made to improve listening, it is only one student that said this application is for learning English generally. There are students that start to understand what the speakers says, can respond and received it. And also the students get know new word, how to pronounce it and how to write it. The application is easy to get and used. And surprisingly this application has many benefit beside to improve listening, some of the participant could improve speaking and their reading. Then the student who used it would be enjoy when learn English especially in listening activity. The other reasons, many series could help the learners practice sustainable every time and everywhere using smartphones. Podcasts application focuses on the capability listening of the users, thus there is a student said that this application make learning english easier and improve four skills in English 
especially listening ability. Moreover, student said that podcast has attractive speaker, it is evident that the speech speakers are very clear and fluent with the right intonation, it makes the listener want to imitate. Therefore, podcast application enhances new vocabularies, such as touchline, frouning, keep the shape, huffed, puffed, footwork, tiptoeing, etc in theme "whose game is it?". In series 2 episode 1 talks about job interview, it is useful for student who just graduated from their school and looking for the job. There is an explanation about how to make a good CV. The researchers analyzed one of conversations that states English is good language to do anything like looking for job or bussines. Therefore, listening activity using podcast resulted many knowledges. In addition, a 5 minutes English episode is better then a long one.

\section{CONCLUSION}

In this era so many ways to improve English skills for better, one of them is using the application in the smartphone to improve it. In brief, Learning English Podcast - Free English Listening Application has an impact for students to learning English well. In other words, this application could improve English ability especially listening skill.

\section{ACKNOWLEDGMENTS}

The research for this paper was financially supported by the Yogyakarta Research. Thank you developing the ideas presented here. The researchers thank to the lecturer, Cynantia R,M.M.Pd who has patiently acompanied the researchers during the process of this research. Then, the researchers also thank to the participant of this research and audiences in Professional Journal of English Education (PROJECT), and IKIP Siliwangi for the work being published.

\section{REFERENCES}

Ang, G. (2009). Oral Communication. Quezon City: Katha Publishing Co., INC.

Aplikasi Belajar Bahasa Inggris Kami. (2018). Taken from British Council Indonesia: https://www.britishcouncil.id/bahasa-inggris/aplikasi

Kline, J. (1996). The Process of Listening. Air University Press.

Morreale, S. P., Spitzberg, B. H., \& Barge, J. K. (2007). Human Communication: Motivation, Knowledege and Skills. USA: Thomson Wadsworth.

Wolvin, A. D. (2010). Listening and Human Communication in 21st Century. United Kingdom: Wiley-Blackwell. 